\title{
Development in broaching technology Part II. Development of broaching methods and tooling devices on CNC machine tools
}

\author{
Postęp w obróbce przeciąganiem \\ Część II. Rozwój sposobów przeciągania \\ i oprzyrządowania narzędziowego na obrabiarkach CNC
}

The paper structured into three parts outlines the present state of the broaching technology. The first part (Mechanik 5-6, 2021) highlighted possible process variants for internal and external operations and designs of broaching machines as well as CNC control systems and other advanced automatization forms. The second part is devoted to the progressive broaching methods such as rotary broaching, hard broaching and MQL application. The third part will discuss some important directions of experimental investigations carrying out for more efficient and reliable broaching processes.

KEYWORDS: broaching technology, broaching machines, broaching tools

W artykule przedstawiono aktualny stan obróbki przeciąganiem z podziałem na trzy części. W pierwszej części (Mechanik 5-6, 2021) opisano odmiany procesu i konstrukcje obrabiarek ze szczególnym uwzględnieniem napędu ruchu głównego, sterowania CNC i zaawansowanych form automatyzacji. W drugiej części dokonano przeglądu sposobów przeciągania, takich jak przeciąganie obrotowe, materiałów utwardzonych i obróbka MQL. W trzeciej części zostaną omówione ważne kierunki prowadzonych badań doświadczalnych procesu przeciągania.

SŁOWA KLUCZOWE: przeciąganie, przeciągarki, przeciągacze

\section{Wprowadzenie}

Przeciąganie należy do sposobów obróbki skrawaniem, w których zasadniczo jako narzędzie kształtowe stosuje się przeciągacz o budowie jednolitej lub składanej oraz zespoły przeciągaczy. Naddatek obróbkowy jest usuwany kolejno przez pojedyncze ostrza lub grupę ostrzy o podobnej geometrii, w trybie warstwa po warstwie, ze stałą prędkością. W pierwszej części artykułu [1] opisano odmiany procesu przeciągania i konstrukcje obrabiarek.

\section{Przeciąganie na obrabiarkach specjalnych}

\section{Przeciaganie śrubowe (helical broaching)}

Jak wspomniano w pierwszej części artykułu [1], pionowe przeciągarki śrubowe CNC typu table-up z napędem elektromechanicznym mogą nadawać przeciągaczowi ruch obrotowy bez potrzeby stosowania dodatkowych elementów (trzpieni) prowadzących. Kąt pochylenia linii śrubowej rowka jest nastawiany elektronicznie, w zależności od zmierzonego kąta pochylenia linii śrubowej ostrzy przeciągacza.

$\mathrm{Na}$ rys. 1 przedstawiono konstrukcję składanego przeciągacza z ostrzami śrubowymi. Ważnym zagadnieniem konstrukcyjnym jest dobór odpowiedniej pojemności rowka wiórowego (rys. 2), która wpływa na

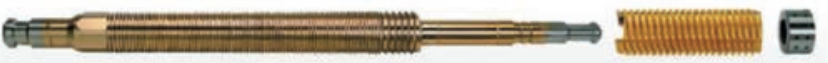

Fig. 1. Indexable broaching tool with helical teeth [14]

Rys. 1. Konstrukcja składanego przeciągacza z ostrzami śrubowymi [14]

a)

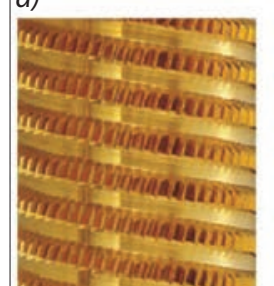

$\left.b_{1}\right)$

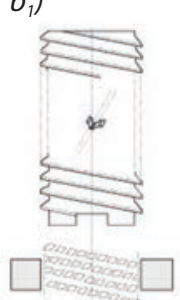

$\left.b_{2}\right)$

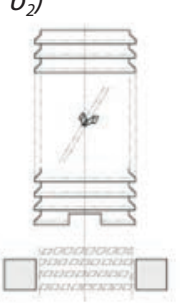

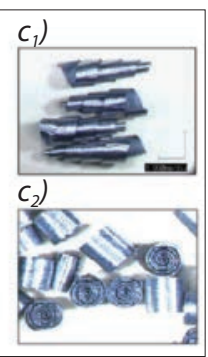

Fig. 2. A view of broaching tool with helical teeth (a) and comparison of chip spaces: $b_{1}$ ) helical teeth/lower chip space, $b_{2}$ ) normal teeth/ /normal chip space, and chip shapes: $c_{1}$ ) helical teeth - conical spiral chips, $c_{2}$ ) normal teeth - flat spiral chips [15]

Rys. 2. Ostrze przeciągacza z ostrzami śrubowymi (a), porównanie pojemności rowków wiórowych: $b_{1}$ ) ostrza skośne/zmniejszone rowki wiórowe, $b_{2}$ ) ostrza prostopadłe/normalne rowki wiórowe, oraz kształty wiórów: $c_{1}$ ) ostrza skośne - wióry spiralne stożkowe, $c_{2}$ ) ostrza prostopadłe - wióry spiralne płaskie [15]

\footnotetext{
* Prof. dr hab. inż. Wit Grzesik, w.grzesik@po.edu.pl, https://orcid.org/0000-0003-3898-5119 - Katedra Technologii Maszyn i Materiałoznawstwa Politechniki Opolskiej, Opole, Polska
} 
TABLE. Characteristics of helical broaching process with different types of chip grooves [15]

TABLICA. Charakterystyka procesu przeciągania śrubowego $z$ różnymi wariantami konstrukcji rowków wiórowych [15]

\begin{tabular}{|c|c|c|c|c|}
\hline \multicolumn{2}{|c|}{ Cechy } & $\begin{array}{c}\text { Prostopadły } \\
\text { do osi }\end{array}$ & Zmniejszony & Normalny \\
\hline \multirow{3}{*}{ 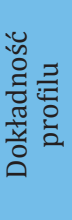 } & $\begin{array}{l}\text { Zmiana siły } \\
\text { skrawania }\end{array}$ & Duża & Mała & Mała \\
\hline & Błąd zarysu & & (0) & \\
\hline & Błąd prowadzenia & $\triangle$ & (0) & $\triangle$ \\
\hline \multicolumn{2}{|c|}{$\begin{array}{l}\text { Chropowatość } \\
\text { powierzchni }\end{array}$} & $\triangle$ & & \\
\hline \multicolumn{2}{|c|}{ Okres trwałości } & $\triangle$ & (0) & \\
\hline \multicolumn{2}{|c|}{ Koszty wstępne } & & $\triangle$ & $\triangle$ \\
\hline \multicolumn{2}{|c|}{ Koszty bieżące } & $\triangle$ & (1) & O \\
\hline \multicolumn{2}{|c|}{ Łatwość przeszlifowania } & & $\triangle$ & $\triangle$ \\
\hline \multicolumn{5}{|c|}{ Legenda: () - b. dobry $\rightarrow \bigcirc$ - dobry $\rightarrow \triangle$-zły } \\
\hline
\end{tabular}

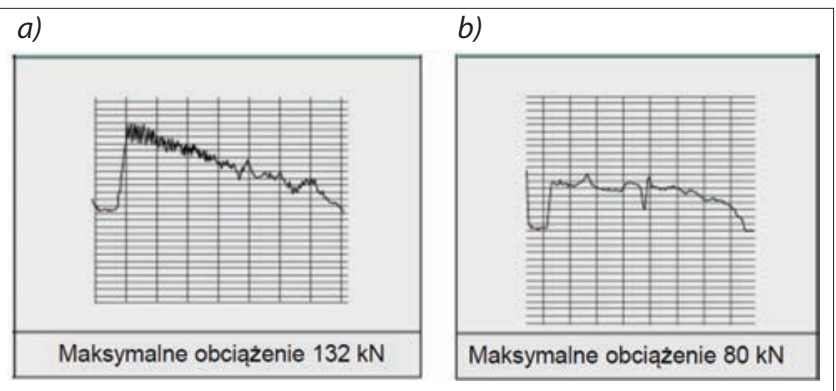

Fig. 3. Comparison of mechanical load distributions for helical broaching tools with: $a$ ) normal and $b$ ) lower chip spaces [15]

Rys. 3. Porównanie przebiegu mechanicznego obciażenia ostrzy przeciągacza z ostrzami śrubowymi z: a) normalną i b) zmniejszoną pojemnością rowków wiórowych [15]

charakterystyki procesu (patrz: tablica) oraz wartość obciążenia mechanicznego i stabilność procesu (rys. 3).

W tablicy porównano charakterystyki przeciągania konwencjonalnego (z ostrzami prostopadłymi do kierunku ruchu głównego) oraz przeciągania śrubowego z normalną i zmniejszoną pojemnością rowków wiórowych. Jak widać, zmniejszenie pojemności rowka wiórowego, czyli efektywna kontrola zwijania wióra (rys. 2c), przyczynia się do wzrostu dokładności przeciąganego zarysu, obniżenia chropowatości powierzchni, wydłużenia trwałości narzędzia i obniżenia kosztów.

$\mathrm{Z}$ praktyki przemysłowej wiadomo, że wewnętrzne przeciąganie śrubowe (rys. $4 a$ ) jest ekonomicznym wyborem w produkcji wielkoseryjnej z małą zmiennością asortymentu (do 30000 szt./miesiąc), ponieważ zapewnia dużą niezawodność procesu. W przypadku większej zmienności produkcji lepszym rozwiązaniem jest wiórkowanie specjalnym narzędziem z trzema sekcjami ostrzy (rys. $4 b$ ).

Na rys. 5 przedstawiono strukturę procesu technologicznego obróbki uzębień wewnętrznych kół pierścieniowych typu broach-grind. Ze względu na trwałość narzędzi toczenie wstępne i przeciąganie prowadzi się w stanie miękkim, tj. gdy twardość materiału wynosi

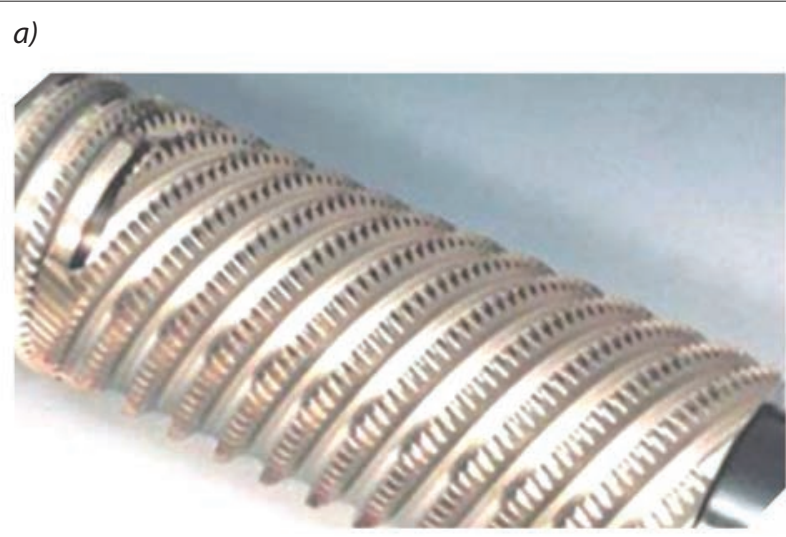

b)

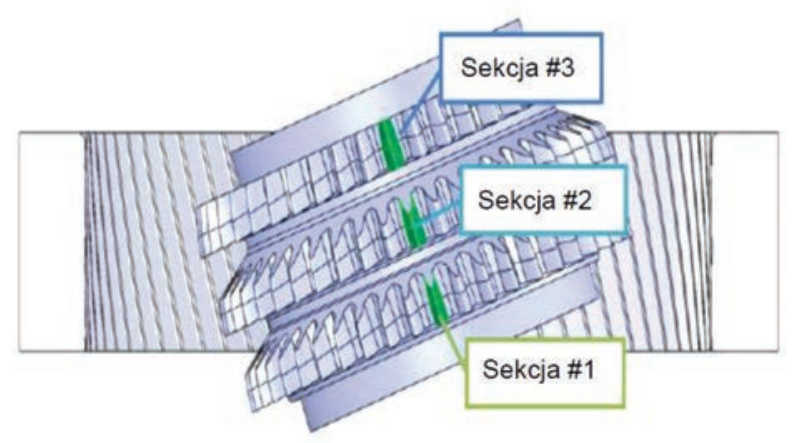

Fig. 4. A view of: $a$ ) helical broaching tool and $b$ ) special shaving tool for inner gears [16]

Rys. 4. Widok: a) przeciągacza z ostrzami śrubowymi i $b$ ) specjalnego wiórkownika do obróbki uzębień wewnętrznych [16]

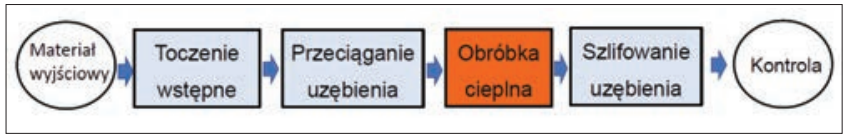

Fig. 5. Structure of a technological chain for machining of inner gears of broach-grind type [16]

Rys. 5. Struktura procesu technologicznego obróbki uzębień wewnętrznych typu broach-grind [16]

$20 \div 30$ HRC, natomiast szlifowanie jest wykańczającą obróbką materiału utwardzonego do 58,60 HRC po azotowaniu $\mathrm{w}$ atmosferze gazowej lub azotonawęglaniu struktury ferrytycznej. Taka struktura procesu technologicznego jest optymalna w przypadku wytwarzania kół przekładni CV i napędów hybrydowych.

\section{Przeciaganie na twardo i $M Q L$}

Przeciąganie na twardo (hard broaching) zostało wprowadzone $\mathrm{w}$ przemyśle - analogicznie jak toczenie, frezowanie czy rozwiercanie i wytaczanie - jako wykańczający proces obróbki części poddanych wcześniej utwardzającej obróbce cieplnej. Jego podstawowym zadaniem jest eliminacja odkształceń powstałych w trakcie obróbki cieplnej i zwiększenie dokładności geometrycznej, głównie podziałki zarysu, oraz zmniejszenie błędów stożkowatości i owalności profili wewnętrznych. Stosuje się narzędzia z nasypem diamentowym i wymiennymi elementami z węglika spiekanego, z powłoką o dużej odporności ściernej. Przeciąganie na twardo zastępuje bardziej kosztowne operacje szlifowania i wycinania elektroerozyjnego (WEDM). Są zasadniczo dwie odmiany tego procesu [13]: 
- Przeciąganie bez zdefiniowanego naddatku obróbkowego (re-broaching), gdy przeciągacz wstępny i do usuwania zniekształceń profilu w wyniku obróbki cieplnej mają ten sam profil. Obróbka nie dotyczy całego profilu, ale fragmentów, w których wystąpiły zniekształcenia. Takie rozwiązanie jest standardem w produkcji kół zębatych synchronizatorów w skrzyniach biegów.

- Przeciąganie ze zdefiniowanym naddatkiem obróbkowym około $0,05 \mathrm{~mm}$ na stronę. Konstrukcja przeciągacza musi uwzględniać wartości odkształceń cieplnych, a obróbce podlegają wszystkie powierzchnie zarysu. Ten wariant jest stosowany $\mathrm{w}$ obróbce współpracujących kół zębatych ze zwiększonym przyleganiem zębów (wymaganiem cichobieżności).

Przeciągacz składany do obróbki na twardo (rys. 6a) jest złożony z trzech części: trzpienia z chwytem ze stali szybkotnącej (HSS) lub stali azotowanej plazmowo (1), części prowadzącej przedniej z HSS (2) i tulei z ostrzami przeciągającymi z węglika spiekanego z powłoką TiAlN (3). Proces przeciągania prowadzi się zwykle z prędkością około $60 \mathrm{~m} / \mathrm{min}$.

Przykłady przeciąganych profili wewnętrznych przedstawiono na rys. $6 b$. Do przeciągania najlepiej się nadają stale utwardzane powierzchniowo (np. nawęglane) lub hartowane indukcyjnie o twardości $58 \pm 2$ HRC.
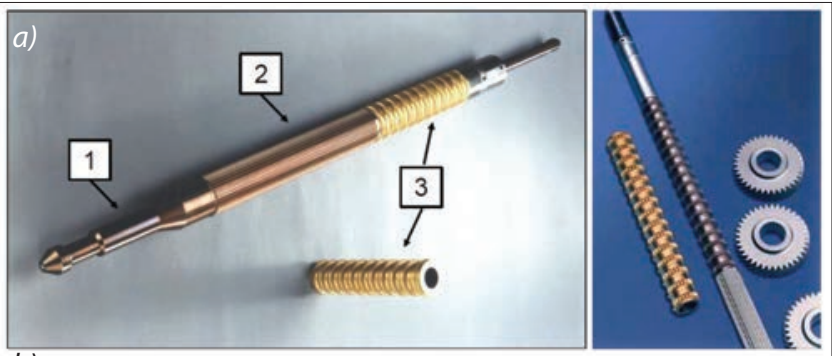

b)

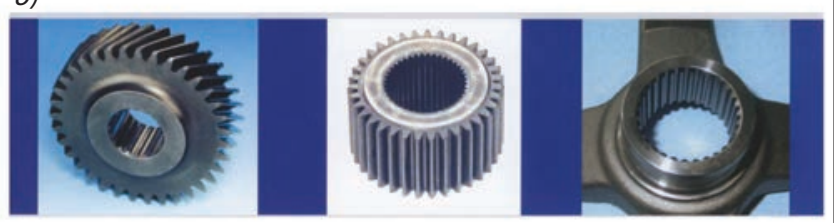

Fig. 6. Indexable broaching tool for hard broaching operations (a) and examples of broaching parts (b) [13] (source: www.oswald-raeumtechnik.com)

Rys. 6. Konstrukcja przeciągacza składanego do obróbki materiałów utwardzonych (a) i przykłady obrabianych części (b) [13] (źródło: www.oswald-raeumtechnik.com)

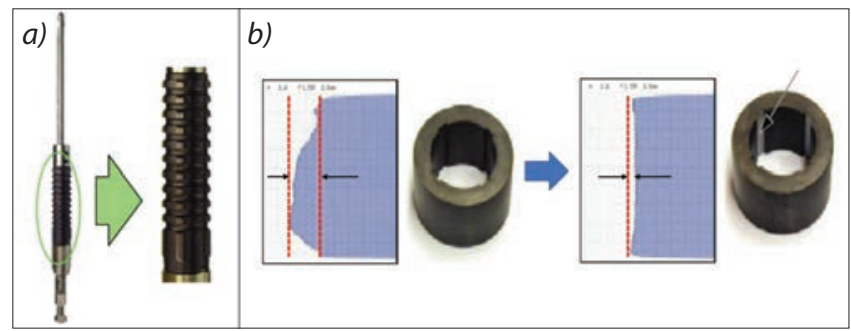

Fig. 7. A view of inner spline broaching tool $(a)$ and comparison of the accuracy of groove shapes after thermal treatment and hard broaching (deviations of the square groove shape) (b) [15]. Workpiece material: SCM420 steel ( $60 \mathrm{HRC})$, semi-dry machining, cutting speed: $60 \mathrm{~m} / \mathrm{min}$

Rys. 7. Widok przeciaggacza do obróbki otworu wielorowkowego $(a)$ i porównanie dokładności rowka po obróbce cieplnej i przeciąganiu (błędu zarysu rowka kwadratowego) (b) [15]. Materiał obrabiany: stal SCM420 (60 HRC), obróbka na półsucho, prędkość skrawania: $60 \mathrm{~m} / \mathrm{min}$
Części azotowane nie powinny być przeciągane z uwagi na bardzo twardą strukturę krystaliczną i zwiększone zużycie ostrzy narzędzia. Grubość warstwy przeciąganej przyjmuje się w zakresie 0,008 $\div 0,015 \mathrm{~mm}$. Uzyskuje się tolerancję kształtu zarysu i prowadzenia IT7. W przypadku kół zębatych z przeciąganymi na twardo profilami wewnętrznymi, które są następnie nasadzane wciskowo na wałek w procesie montażu, zwiększa się wyraźnie przenoszony moment obrotowy.

$\mathrm{Z}$ rys. 7 wynika, że odchyłka zarysu rowka kwadratowego $\mathrm{w}$ otworze wielorowkowym zmniejsza się z $21 \mu \mathrm{m}$ po obróbce cieplnej do $3 \mu \mathrm{m}$ po przeciąganiu.

$\mathrm{Z}$ rys. 8 - na którym porównano szlifowanie i przeciąganie na twardo - wynika, że procesy te mają wyraźnie odmienną strukturę kosztów maszynowych. W przeciąganiu na twardo - co jest oczywiste - dużo

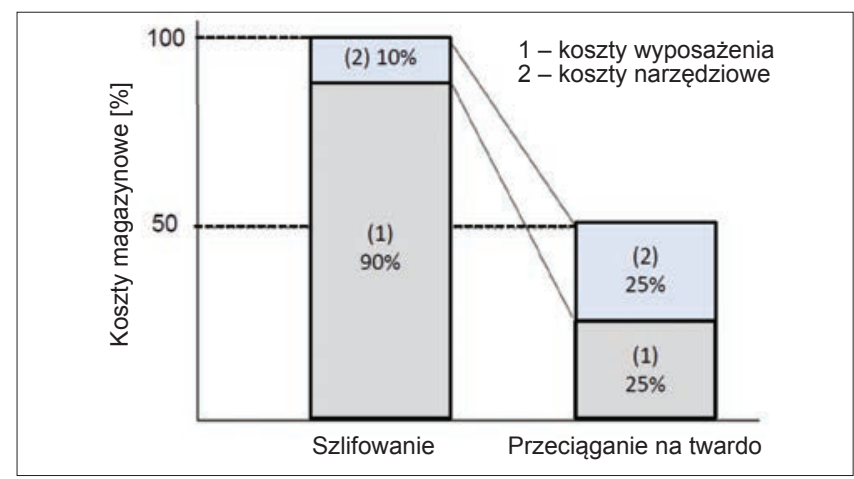

Fig. 8. Comparison of cost structures for grinding and hard broaching [15]

Rys. 8. Porównanie struktury kosztów w szlifowaniu i przeciąganiu na twardo [15]

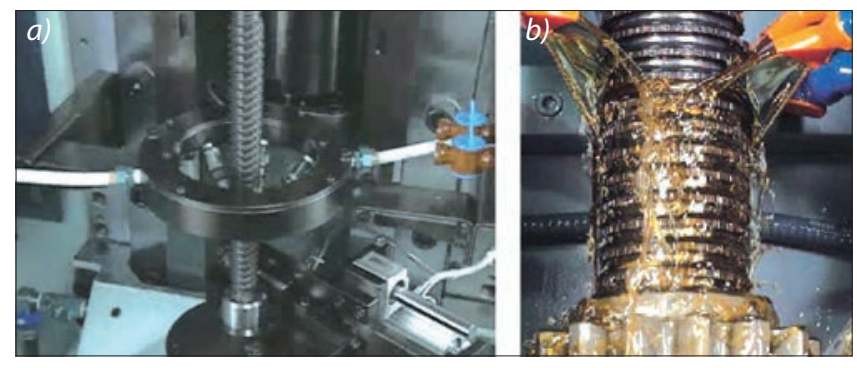

Fig. 9. Visual comparison of broaching operations with minimum (MQL) (a) and wet oil lubrication (b) [15]

Rys. 9. Porównanie przeciągania z minimalnym (a) i obfitym smarowaniem olejowym (b) [15]

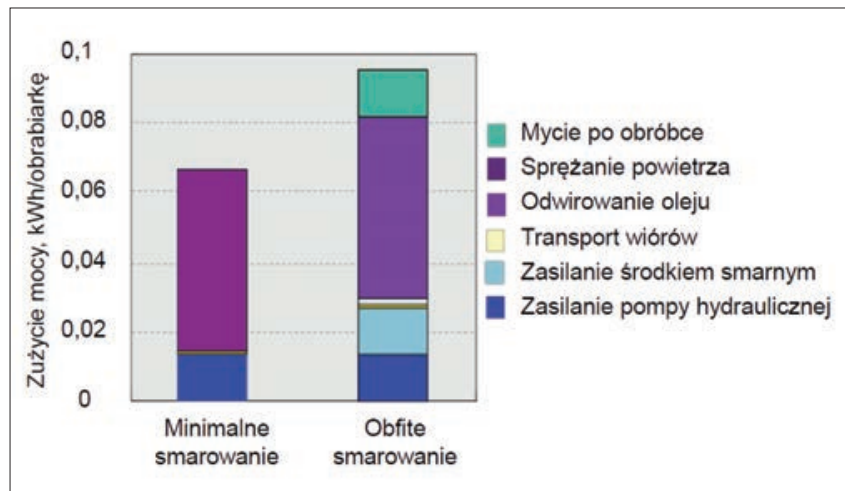

Fig. 10. Compare the power consumption components of broaching operations with: minimum (MQL) and wet oil lubrication [15]

Rys. 10. Porównanie składników zużycia mocy w przeciąganiu: z minimalnym (na półsucho) i obfitym smarowaniem olejowym [15] 
wyższe są koszty narzędziowe (25\% vs $10 \%)$. Z kolei w szlifowaniu dominują koszty wyposażenia ( $90 \%$ vs $25 \%)$.

Na rys. 9 przedstawiono procesy przeciągania na półsucho (MQL) i z obfitym smarowaniem olejowym, a na rys. 10 porównano składniki zużycia mocy odpowiadające tym odmianom sposobów smarowania/ /chłodzenia. W przypadku obróbki na półsucho eliminuje się składniki mocy przypadające na pracę pompy do zasilania chłodziwa olejowego oraz oddzielanie oleju z wiórów w separatorze odśrodkowym. Nie ma też konieczności przeprowadzania mycia po zakończeniu procesu. Ponieważ w obróbce z minimalnym smarowaniem używa się niewielkich ilości oleju roślinnego lub syntetycznego, nie występuje tu problem usuwania chloru z wiórów przed ich recyklingiem. Należy dodać, że wióry śrubowe stożkowe (rys. $2 c_{1}$ ) łatwiej się oprowadza i nie zakleszczają się one $\mathrm{w}$ rowkach wiórowych narzędzia.

\section{Przeciaganie rowków $w$ wirnikach turbin}

Jak podano w pierwszej części artykułu [1], do wykonywania rowków $\mathrm{w}$ wirnikach sprężarek i turbin silników odrzutowych stosuje się specjalne przeciągacze do rowków na jaskółczy ogon (dove tail type broach) i jodełkowych (fir/Christmas tree broach). Zasadę podziału naddatku obróbkowego w przekroju rowka jodełkowego przedstawiono na rys. 11a. Naddatek jest usuwany a)

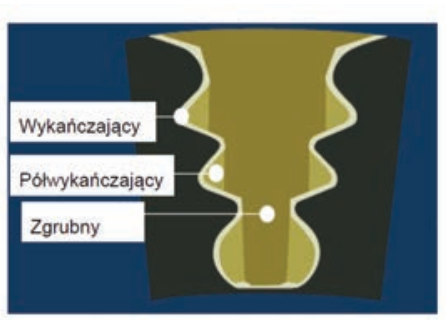

b)

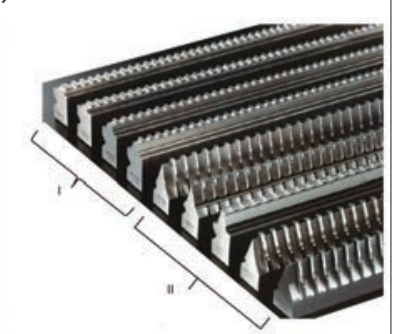

Fig. 11. A scheme of material allowance distribution in broaching fir/ Christmas tree grooves in jet turbine discs $(a)$ and sets of broaching tools for dovetail shaped (I) and fir/Christmas tree shaped (II) grooves (b) [13] (source: www.oswald-raeumtechnik.com)

Rys. 11. Podział naddatku obróbkowego w przeciąganiu rowków jodełkowych w wirnikach turbin (a) i zestawy przeciągaczy do rowków na jaskółczy ogon (I) i jodełkowych (II) (b) [13] (źródło: www.oswaldraeumtechnik.com)

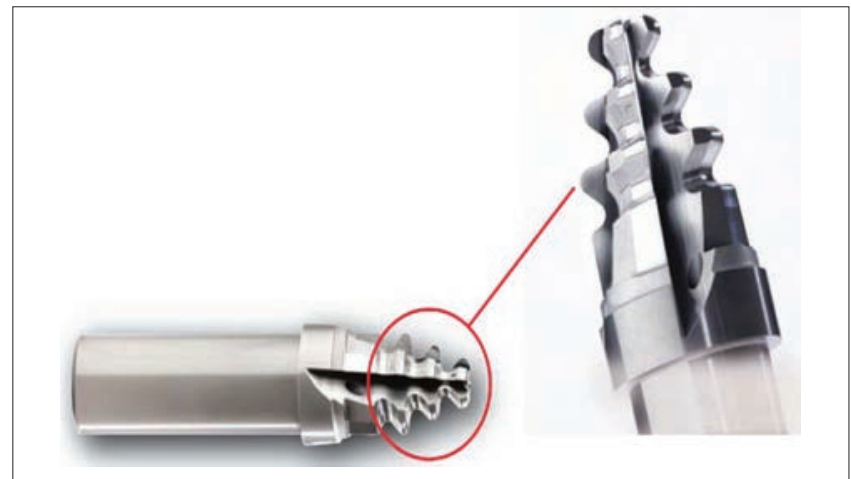

Fig. 12. A special formed cutter for fir tree shaped grooves in turbine discs for jet engines [13]

Rys. 12. Konstrukcja frezu kształtowego do wykonywania rowków jodełkowych w wirnikach turbin [13] przez przeciągacz zgrubny, półwykańczający i wykańczający. Stosuje się zestawy nawet więcej niż 10 przeciągaczy o różnym zarysie ostrzy (rys. 11b), wykonanych z ultradrobnych stali proszkowych PM HSS o bardzo dużej odporności na ścieranie. W projektowaniu narzędzi uwzględnia się materiał obrabiany, długość przeciąganego zarysu oraz charakterystykę przeciągarki.

W przypadkach uzasadnionych ekonomicznie do wykonywania rowków jodełkowych stosuje się specjalne kształtowe frezy monolityczne przedstawione na rys. 12. Frezy te wykonuje się z ultradrobnych węglików spiekanych i mają one powłokę (TiAlN+AlTiCR) o wysokiej odporności termicznej $\left(1200^{\circ} \mathrm{C}\right)$ [13].

\section{Przeciąganie na innych obrabiarkach CNC}

\section{Przeciaganie rotacyjne}

Przeciąganie rotacyjne (rotary broaching) jest realizowane na tokarkach $\mathrm{CNC}$, frezarkach $\mathrm{CNC}$, wieloosiowych centrach tokarskich i centrach obróbkowych. Wewnętrzne i zewnętrzne, regularne, nieobrotowe, ślepe i przelotowe profile o różnych kształtach (rys. 13) mogą być wykonywane w częściach z różnych materiałów - aluminium, stali, mosiądzu, tytanu i tworzyw sztucznych. Ta metoda nadaje się zwłaszcza do wykonywania gniazd w elementach złącznych (fasteners), z których najbardziej popularne jest gniazdo sześciokątne znane pod firmowym znakiem

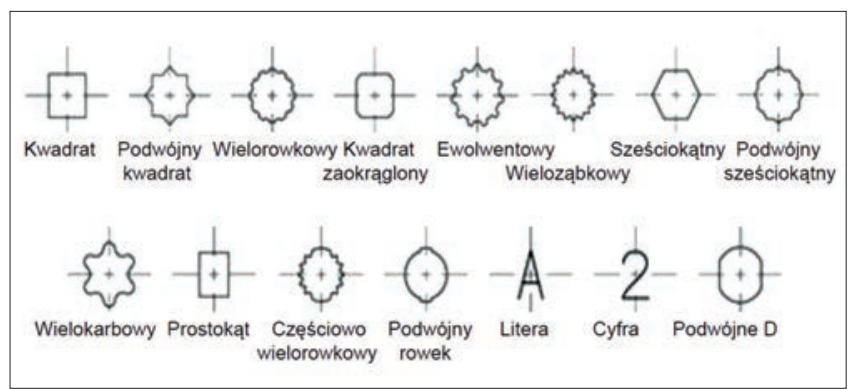

Fig. 13. Examples of inner profiles producing by rotary broaching Rys. 13. Przykłady zarysów wewnętrznych wykonywanych przez przeciąganie rotacyjne

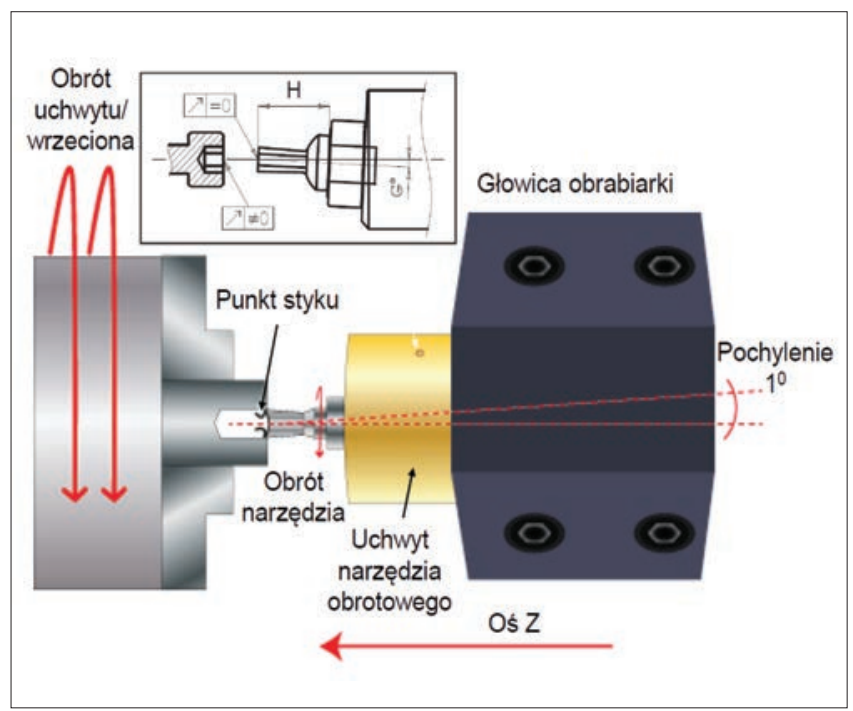

Fig. 14. Principle of rotary broaching performed on a CNC lathe [17] Rys. 14. Zasada przeciagania rotacyjnego na tokarce CNC [17] 


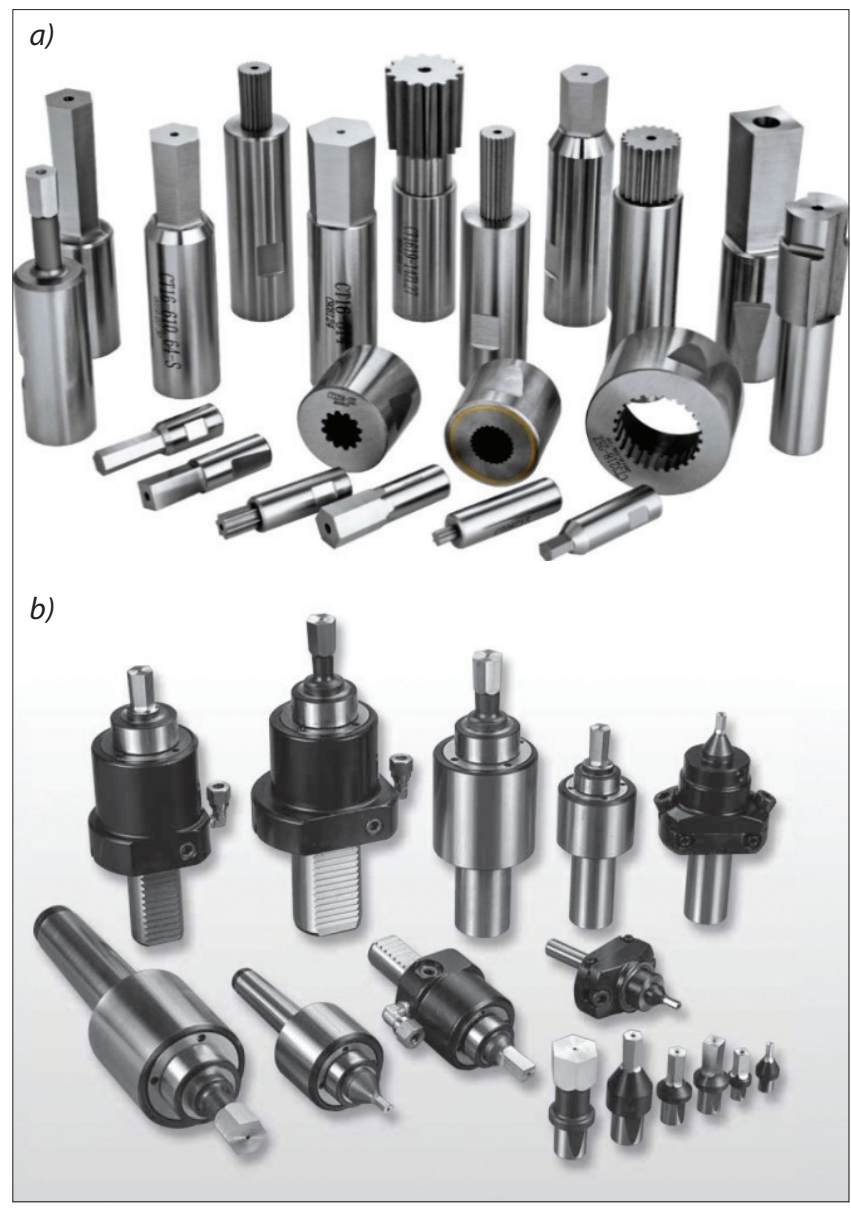

Fig. 15. A set of broaching tools for different inner profiles $(a)$ and tool holders applied $(b)[19,20]$

Rys. 15. Zestaw narzędzi do przeciągania rotacyjnego różnych profili wewnętrznych (a) i uchwyt narzędzia $(b)[19,20]$

Torx ${ }^{\circledR}$ [17]. Elementy złączne stosuje się w przemyśle lotniczym, motoryzacyjnym, hydraulicznym, medycznym i montażu konstrukcji.

Zasadę przeciągania rotacyjnego przedstawiono na rys. 14 . Specjalne narzędzie wykonane z kątem przyłożenia $1^{\circ} 30^{\prime}$ jest ustawione w uchwycie pod kątem $1^{\circ} \mathrm{w}$ stosunku do osi przedmiotu. Wymiar $H$ podawany przez producenta zapewnia dokładne ustawienie narzędzia w osi obrotu. Uchwyt przeciągacza obrotowego ma wrzeciono, które obraca się niezależnie od jego reszty. W chwili styku stacjonarnego narzędzia z przedmiotem zostaje wymuszony jego synchroniczny ruch obrotowy (wirowanie) wskutek sił tarcia [18]. Wierzchołek ostrza utrzymuje pozycję w osi obrotu przedmiotu, natomiast pozostała część krawędzi skrawającej wykonuje ruch oscylacyjny wokół osi obrotu, co wywołuje efekt bicia osiowego podobny do mimośrodowego obrotu krzywki. W ten sposób czynna część krawędzi skrawającej wcina się periodycznie w materiał i wychodzi z niego, a wymagany zarys wewnętrzny tworzy się przez oddzielanie półokrągłych fragmentów materiału na obwodzie (scalloping effect).

W przypadku tokarek w czasie procesu obraca się przedmiot i narzędzie, natomiast zatrzymywany jest obrót uchwytu. W przypadku frezarek i innych obrabiarek z narzędziem obrotowym narzędzie i uchwyt są przemieszczane $\mathrm{w}$ kierunku przedmiotu i w chwili styku obrót narzędzia i przedmiotu jest zatrzymywany, a pozostaje obrót uchwytu narzędzia.

Na rys. $15 a$ przedstawiono zestaw narzędzi do przeciągania rotacyjnego różnych profili wewnętrznych z rys. 13. Stosuje się uchwyty z chwytem walcowym, stożkowym Morse'a i VDI (rys. 15b). Zasady centrowania narzędzia i przygotowania otworu wstępnego podają producenci przeciągaczy obrotowych i oprzyrządowania [17-20].

\section{Przeciaganie zarysów wewnętrznych i zewnętrznych na centrach obróbkowych}

Prawie wszystkie rodzaje rowków, wewnętrznych i zewnętrznych, mogą być wykonywane na tokarkach uniwersalnych, tokarkach CNC z programowanymi osiami $Y$ i $C$, tokarkach wielowrzecionowych, frezarkach CNC sterowanych w trzech i pięciu osiach oraz centrach obróbkowych. Ograniczenia mogą dotyczyć obrabiarek z wrzecionami z łożyskami ceramicznymi i specjalnych obrabiarek HSM. W przypadku obrabiarek CTX beta i CTX gamma firmy DMG MORI [21] przeciąganie rowków oraz ogólnie obróbka zarysów i uzębień wewnętrznych (rys. 16a) są jednym z 42 dostępnych cykli obróbkowych. Obróbka otworów wielorowkowych i wałków wielowypustowych odbywa się za pomocą programowania dialogowego. Możliwe jest stosowanie narzędzi z pojedynczym lub wielokrotnym (do czterech ostrzy) zarysem. Kompensacja parametrów obróbki następuje, gdy pojawia się odchylenie w ustawieniu uchwytu narzędzia w osi $X$. Chwyt narzędzia (rys. 16b) jest mocowany w tulei mimośrodowej umożliwiającej ustawienie wymaganego pochylenia w stosunku do osi przedmiotu, gdy tokarka nie ma sterowanej osi $Y$. W ten sposób dokonuje się przemieszczenia wzdłuż osi $(+Y)$ i $(-Y)$ o $0,5 \mathrm{~mm}$.

Na rys. 17 zaprezentowano rozwiązania konstrukcyjne typowych narzędzi do przeciągania zarysów wewnętrznych i zewnętrznych. W zestawie przeciągaczy do rowków wpustowych (rys. 17a) są trzy płytki skrawające, które służą do wykonywania rowków pasowanych w klasach JS9, P9 i C11 według norm DIN. Oprawki narzędziowe mają uchwyty VDI, Capto lub HSK. Rowki pochyłe i śrubowe wykonuje się z zastosowaniem sterowania w osiach $C$ i $X$. Na rys. $17 c$ i $17 d$ przedstawiono przeciągacz jednoostrzowy i przeciągacz

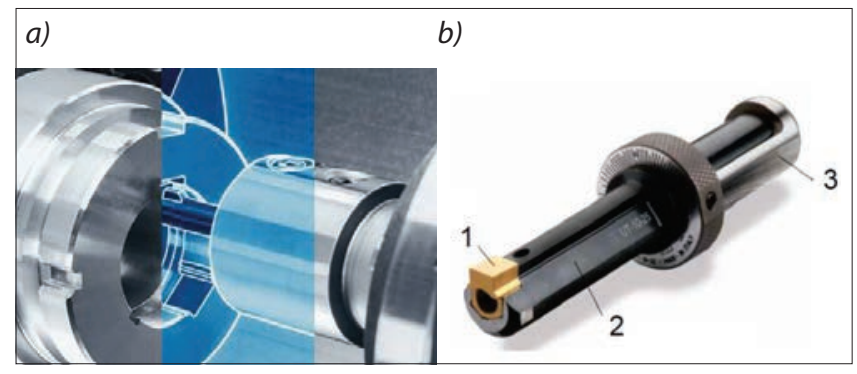

Rys. 16. Principle of keyway broaching on machining centre $(a)$ and elements of indexable tools (b). Symbols: 1 - cutting insert, 2 - insert holder, 3 - accentric bushing [21,22]

Rys. 16. Zasada przeciągania rowka wpustowego na centrum obróbkowym (a) i budowa narzędzia składanego (b). Oznaczenia: 1 - płytka skrawająca, 2 - oprawka, 3 - tuleja mimośrodowa [21, 22] 


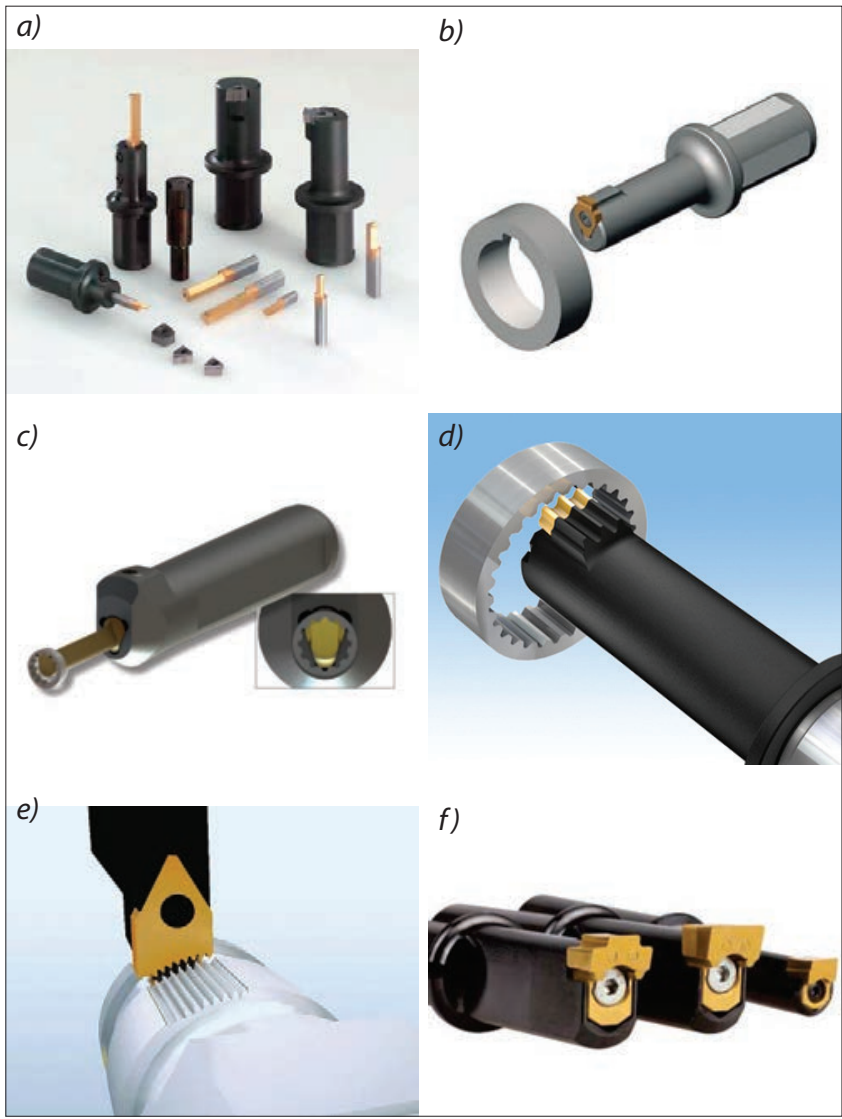

Fig. 17. Examples of broaching systems for producing: $a$ ) keyways by Horn $[23], b$ ) single keyway, $c$ ) internal splines using insert with one tooth by Horn [23], d) internal splines using insert with multiple teeth by Iscar [25], e) serrated outer profile using insert with multiply teeth [11]; $f$ ) set of three broaching tools for making the magazine reliefs square grooves (magwell type) by duPont [26]

Rys. 17. Przykłady rozwiązań konstrukcyjnych systemów przeciągaczy do obróbki: a) rowków wpustowych firmy Horn [23], b) rowka wpustowego, c) otworów wielorowkowych płytką z zarysem pojedynczym firmy Horn [23], d) otworów wielorowkowych płytką z zarysem wielokrotnym firmy Iscar [25], e) zarysu wieloząbkowego płytką wielokrotną [11]; f) zestaw trzech przeciagaczy do obróbki uchwytu magazynka typu magwell firmy duPont [26]

wieloostrzowy do wykonywania otworów wielorowkowych. Zasadniczo tego typu narzędzia są wykonywane z jednym lub wieloma ostrzami zgrubnymi i jednym ostrzem wykańczającym. Przykładem tego drugiego rozwiązania jest przeciągacz do wykonywania zewnętrznego zarysu wieloząbkowego - rys. 17e. Na rys. $17 f$ przedstawiono zestaw trzech przeciągaczy do obróbki uchwytu magazynka typu magwell firmy duMont.

W tokarkach CNC z głowicą rewolwerową i centrach obróbkowych narzędzia mocuje się $\mathrm{w}$ specjalnych głowicach napędzanych przedstawionych na rys. 18. Dodatkowo stosuje się adaptery umożliwiające zamocowanie różnych narzędzi. Na rys. $18 a$ i $18 b$ przedstawiono głowice osiowe i promieniowe $\mathrm{z}$ różnymi uchwytami mocującymi. Interesujące jest rozwiązanie uniwersalnej głowicy do mocowania przeciągacza do rowków (rys. 18c), którą można wykonać rowek wewnętrzny, a po obrocie głowicy o $180^{\circ}$ - także rowek zewnętrzny.

Na rys. 19 przestawiono możliwości techniczne zastosowania głowic do przeciągania na centrach obróbkowych.
Przeciąganie zapewnia wiele korzyści jako alternatywny proces obróbki przeprowadzany na tokarkach CNC i centrach obróbkowych. Należą do nich: mniejsze koszty narzędziowe, obróbka w jednym zamocowaniu, mniejsze koszty produkowanych części, szybsze i elastyczne operacje w małych i średnich seriach oraz w wytwarzaniu prototypów, uproszczona produkcja złożonych profili specjalnych i programowanie obróbki.

Rozwój narzędzi do przeciągania wiąże się ściśle $\mathrm{z}$ wprowadzaniem nowych materiałów narzędziowych i nakładaniem specjalnych powłok. Napędzane głowice do mocowania przeciągaczy są ważnym elementem, który skraca czas jednostkowy obróbki, tak jak programowanie nowych cykli obróbkowych może znacznie uprościć zastosowanie konwencjonalnego przeciągania.

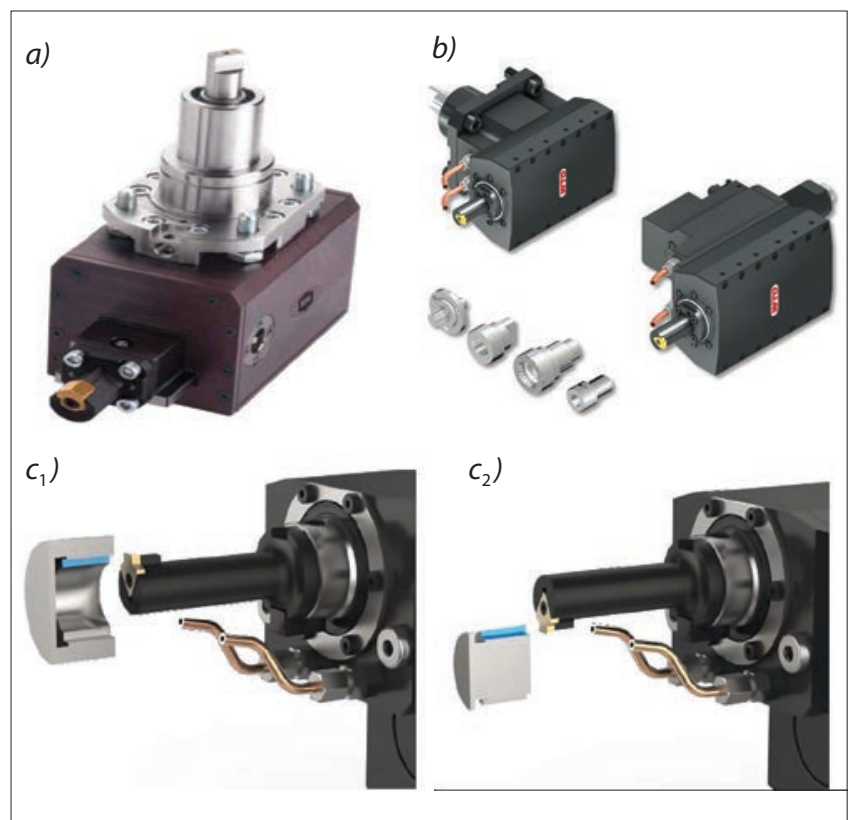

Fig. 18. Examples of powered heads (units) for broaching tools: a) for keyways [20], b) a set of powered heads for machining centres [23] (source: www.wto-usa.com), c) radial heads for broaching both internal $\left(c_{1}\right)$ and external $\left(c_{2}\right)$ keyways [27]

Rys. 18. Przykłady rozwiązań głowic napędzanych do przeciągaczy: a) do obróbki rowków wpustowych $[20], b$ ) zestaw głowic na centra obróbkowe [23] (źródło: www.wto-usa.com), c) głowica promieniowa do równoczesnego przeciągania rowków wewnętrznych $\left(c_{1}\right)$ i zewnętrznych $\left(c_{2}\right)$ [27]

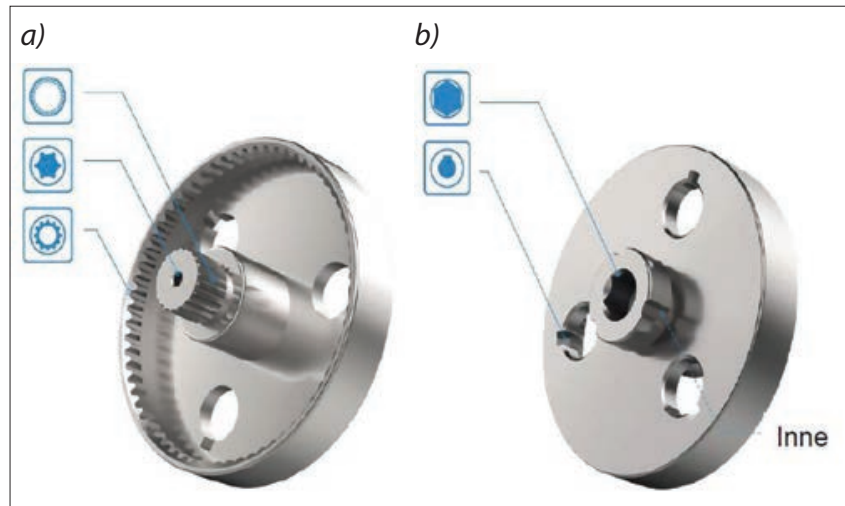

Fig. 19. Examples of the use of powered heads for broaching various profiles [26]

Rys. 19. Przykłady zastosowania głowic napędzanych do przeciągania różnych profili [26] 


\section{LITERATURA}

[1] Grzesik W. "Development in broaching technology. Part I. Development of broaching machines and tooling devices” [„Postęp w obróbce przeciąganiem. Część I. Rozwój przeciagarek i oprzyrządowania narzędziowego"]. Mechanik. 5-6 (2021): 6-11, https://doi org/10.17814/mechanik.2021.5-6.8.

[2] Olszak W. „Obróbka skrawaniem”. Warszawa: PWN (2017).

[3] Toenshoff H.K., Denkena B. "Basic of Cutting and Abrasive Processes". Heidelberg: Springer (2013).

[4] Grzesik W. „Podstawy skrawania materiałów konstrukcyjnych". Warszawa: PWN (2018).

[5] Arrazola J.P., Rech J., M’Saoubi R., Axinte D. "Broaching: Cutting tools and machine tools for manufacturing high quality features in components". CIRP Annals Manufacturing Technology. 69/2 (2020): 554-577, https://doi org/10.1016/j.cirp.2020.05.010.

[6] McGuinn J. "Broaching in the 21st Century". Gear Technology. (May 2018): 26-30, www. geartechnology.com.

[7] Stott W.R. "State-of-the-art broaching". Gear Technology. (August 2011): 62-66, www. geartechnology.com.

[8] Schulze V. "Broaching". "CIRP Encyclopaedia of Production Engineering". 2014 Edition, doi: https://doi. org/10.1007/978-3-642-20617-7_6686.

[9] Desrochers C., Bryant K. "An update on broaching technology". Gear Solution Magazine. (March 2016), www. gearsolution.com.

[10] Cannella A. "The latest in broaching". Gear Technology. (January/February 2020): 29-31.

[11] Adams L. "Technology advances CNC broaching systems". (2019) www. ctemag.com.
[12] Egrin M. "Advantages of a dual-screw H-frame broaching machine". Gear Solutions. (March 2019): 37-39, www. gearsolutions.com.

[13] "Hard broaching". www.swz-zm.de.

[14] "High performance tools for aerospace applications". Nachi. Aerospace. www.nachiamerica.com.

[15] "Hard broaching". Nachi. www.nachiamerica.com.

[16] Smith D. "Beautiful on the inside. Higher quality internal gears". Gear Technology. (January/February 2019): 54-57, www. mitsubishigearcenter.com.

[17] "Polygon solutions. Shaping the broaching industry", www.polygon.com.

[18] "The basic of rotary broaching". www.productionmachining.com

[19] "KC-CX internal square/hex/spline hss rotary broach/ broaching tool holder". https://www.machineryoffers. com

[20] "Broaching heads". www.chiamo.it.

[21] "42 exclusive DMG Mori technology cycles". www.dmgmori.com.

[22] "Broaching systems on CNC machine tools". www.brighetti.it.

[23] "Broaching on CNC Machines". Production Machining. (December 2011), www.productionmachining.com.

[24] Modic E.E. "High volume ID broaching". Today's Medical Developments. (May 2017) www.todaysmedicaldevelopments.com

[25] "ISCARBROACH: ISCAR's new line of tools simplifies broaching applications". www.iscar.com.

[26] duMont. "Firearm CNC broaching kit". www.pilotprecision.com.

[27] "Tooling technology. LinTec broaching units". www. benz-tools.com. 